TITLE:

\title{
Nucleolar characteristics of reducing bodies in reducing body myopathy(Abstract_要旨)
}

\author{
AUTHOR(S): \\ Shinde, Akiyo
}

\section{CITATION:}

Shinde, Akiyo. Nucleolar characteristics of reducing bodies in reducing body myopathy. 京都大学, 2007, 博士(医学)

ISSUE DATE:

2007-05-23

URL:

http://hdl.handle.net/2433/135903

RIGHT: 
氏 名筯出䐺点

学位(専攻分野) 博士 (医学)

学位記番号論医博第 1930 号

学位授与の日付 平成 19 年 5 月 23 日

学位授与の要件 学 位 規 則第 4 条第 2 項 該 当

学位論文題目 Nucleolar characteristics of reducing bodies in reducing body myopathy

（還元小体ミオパチーに認められる還元小体は核小体の性質をもつ）



\section{論文 内容 の 要 旨}

還元小体ミオパチー（RBM）は筋線維内に還元小体という異常封入体がみられるまれな骨格筋疾患である。還元小体の 構成成分は組織化学染色の結果より, ある種の還元作用を持つ蛋白であると推定されている。すなわち還元小体とは, 患者 生検骨格筋の $\alpha$-glycerophosphate dehydrogenaseの組織化学染色において，基質である $\alpha$-glycerophosphateを反応溶液 中に加えなくても menadione存在下でnitroblue tetrazolium を還元し, 発色・同定されることからこの名前がつけられた。 この還元能はスルフヒドリル基を含むタンパク質に起因していることが示唆されているが，正確な起源は明らかにされてい ない。その他，還元小体はRNAも含んで抢り，電顕では顆粒状構造物が密に集合した像として観察される。この研究によ り，還元小体は核小体成分が細胞質に異常に出現したものと推定するに至った。検討した症例は33歳女性で，左下腿の筋萎 縮が約10年で緩徐に進行した後に，約 1 年で両下肢の筋力低下が，その後約半年で両上肢の筋力低下が進行した。診察上頸 部の rigid spine，上肢近位と下肢遠位筋を中心とした筋力低下を認めた。生検筋の凍結切片を用いた組織学的検討では， Gomori-trichrome変法染色で, 筋線維内に深緑色の封入体を認めた。この封入体は上記の還元小体の性質を有したため, 還元小体ミオパチーと診断した。電子顕微鏡下では, オスミウム親和性の楕円形のスポンジ様の構造物として認められ，従 来の還元小体の微細構造と一致した。還元小体を核小体由来と証明するため，1）電子顕微鏡下での核小体と還元小体の比 較，2）核小体に扔けるリボソームRNA 合成に関与する好銀性タンパク質を，組織学的に検出する AgNOR染色， 3 ）核 小体，リボ核蛋白質に対するモノクローナル抗体を用いた免疫組織化学を行った。結果であるが，1）還元小体を電子顕微 鏡的に検討したところ, 直径 6-18nmの顆粒状の構造物と微細なフィラメントを認め, 正常核小体構造物によく類似して いた。2）AgNOR染色では，還元小体が陽性に染色された。3）還元小体は核小体，リボ核蛋白質に対するモノクローナ 儿抗体で陽性に染色された。以上より，還元小体は核小体の構成成分を含むことが示された。AgNOR法は主に悪性新生物 の増殖能を評価する方法として用いられており, 酸化還元電位を認識する反応である。従って, AgNOR染色法は, 基質非 存在下の $\alpha$-glycerophosphate dehydrogenase の組織化学染色と同じ意味を持つのかもしれない。電顕では，還元小体はし ばしば正常な核に隣接したり，あるいは核を取り巻いたりしている像が観察される。このようなことより，還元小体は核の 崩壞により核小体が細胞質に遊離しているのではなく, 核からリボゾーム前駆体として細胞質へ運搬された後の, リボゾー ムの形成と会合の過程の異常によって引き起こされた可能性があると考えた。結論として，本研究により，リボゾーム前駆 体成分が還元小体を構成している可能性が示された。RBMはリボゾームRNAの適切なプロセシングと会合の欠陥から生 じる疾病であるかもしれない。

\section{論 文 審 査の 結 果の 要 旨}

還元小体ミオパチー（RBM）は筋線維内に還元小体（RB）という異常封入体がみられるきわめて稀な骨格筋疾患である。 本研究では RB の正確な起源を明らかにするため, 筋病理学的検討を行った。対象症例は33歳女性で, 生検筋の組織学的検 
討でRBM と診断した。RBを形態学的に検討する手段として，1）電子顕微鏡下での核小体と RBの比較，2）核小体にお けるリボソームRNA 合成に関与する好銀性タンパク質を組織学的に検出する AgNOR染色, 3) 核小体, リボ核蛋白質に 対するモノクローナル抗体を用いた免疫組織化学を行った。その結果，1）電子顕微鏡下の観察で, RBは正常核小体構造 物に類似していた。2）AgNOR染色で，RBは陽性に染色された。3）RBは核小体，リボ核蛋白質に対するモノクローナ 儿抗体で陽性に染色された。以上より，RBは核小体の構成成分を含むことが示された。さらに電子顕微鏡では，RBはし ばしば正常な核に隣接していることから，核小体が核の崩壊により細胞質に遊離したためではなく，リボゾーム前駆体が細 胞質へ運搬された後に形成された可能性が高いと考えられた。これらの結果から RBMはリボゾーム RNA の適切なプロセ シングと会合の欠陥から生じる疾病であるとの仮説を提唱した。

以上の研究は還元小体ミオパチーでみとめられる還元小体の起源の解明に貢献し, 今後の還元小体ミオパチーの病態の解 明に寄与するところが多い。したがって，本論文は博士（医学）の学位論文として価値あるものとみとめる。

なお，本学位授与申請者は，平成19年 4 月24日実施の論文内容とそれに関連した試問を受け，合格と認められたものであ る。 